\title{
An Unusual Presentation of Esophageal Cancer: A Case Report and Review of Literature
}

\author{
Abraham T. Yacoub $^{\mathrm{a}}$, Regina Frants ${ }^{\mathrm{b}}$, Leslie Bank ${ }^{\mathrm{c}}$, ${ }^{\text {, Jagmohan S. Sidhu }}{ }^{\mathrm{d}}$, Peter Nicholson ${ }^{\mathrm{e}}$
}

\begin{abstract}
We present a case of a 49-year-old white female who complained of a chronic cough for 1 year. Computed tomography (CT) of the chest revealed abnormal thickening of the thoracic esophagus. Esophagogastroduodenoscopy (EGD) revealed diffuse multiple masses in the esophagus, which appeared separate. Histopathology of the masses revealed adenocarcinoma.
\end{abstract}

Keywords: Esophageal adenocarcinoma; Metastatic cancer; Chronic cough

\section{Introduction}

Worldwide, $90 \%$ of esophageal cancers are squamous cell carcinomas (SCCs) and about 5\% are adenocarcinomas [1]. The remaining 5\% represent rare malignancies and metastases from other organs [1]. The most common presenting symptoms are dysphagia, odynophagia, and weight loss [2,3]. It is one of the deadliest cancers worldwide with 5-year survival rates of 5.0$26.2 \%$ and the eighth most common cancer worldwide [4-9]. There are two major types of esophageal cancer: esophageal adenocarcinoma (EAC) and esophageal squamous cell cancer

Manuscript accepted for publication December 09, 2015

${ }^{a}$ Department of Internal Medicine, United Health Services Wilson Medical Center, 33-57 Harrison St, Johnson City, NY, USA

${ }^{b}$ Department of Pulmonary and Critical Care Medicine, United Health Services Wilson Medical Center, 33-57 Harrison St, Johnson City, NY, USA

'United Health Services Wilson Medical Center, Upstate Medical University, Binghamton Gastroenterology Associates, 40 Mitchell Ave., Binghamton, NY 13903, USA

${ }^{\mathrm{d} A n a t o m i c ~ P a t h o l o g y ~ \& ~ C l i n i c a l ~ P a t h o l o g y, ~ H e m a t o l o g y, ~ U n i t e d ~ H e a l t h ~ S e r-~}$ vices Wilson Medical Center, 33-57 Harrison St, Johnson City, NY, USA

eDepartment of Radiology, United Health Services Wilson Medical Center, 33-57 Harrison St, Johnson City, NY, USA

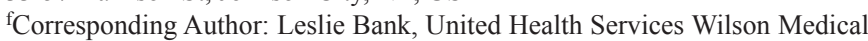
Center, Upstate Medical University, Binghamton Gastroenterology Associates, 40 Mitchell Ave., Binghamton, NY 13903, USA.

Email: leslie.bank@gmail.com

doi: http://dx.doi.org/10.14740/jmc2386w
(ESCC) [10]. EAC arises from the distal third of the esophagus and is commonly found in Caucasian men [7, 11, 12]. ESCC arises from the proximal two-thirds of the esophagus and is commonly found in African Americans and Caucasian females [7, 13-15].

\section{Case Report}

A 49-year-old white female with a past medical history of hypothyroidism and generalized anxiety disorder was referred to our gastroenterology clinic by the pulmonologist for an abnormal finding on the computed tomography (CT) scan of the chest. The patient was evaluated by her pulmonologist for a chronic cough of 1 year duration. Despite three courses of antibiotics, the cough continued to worsen.

She denied any medical history of gastroesophageal reflux disease (GERD), esophagitis, or aspiration pneumonitis. She

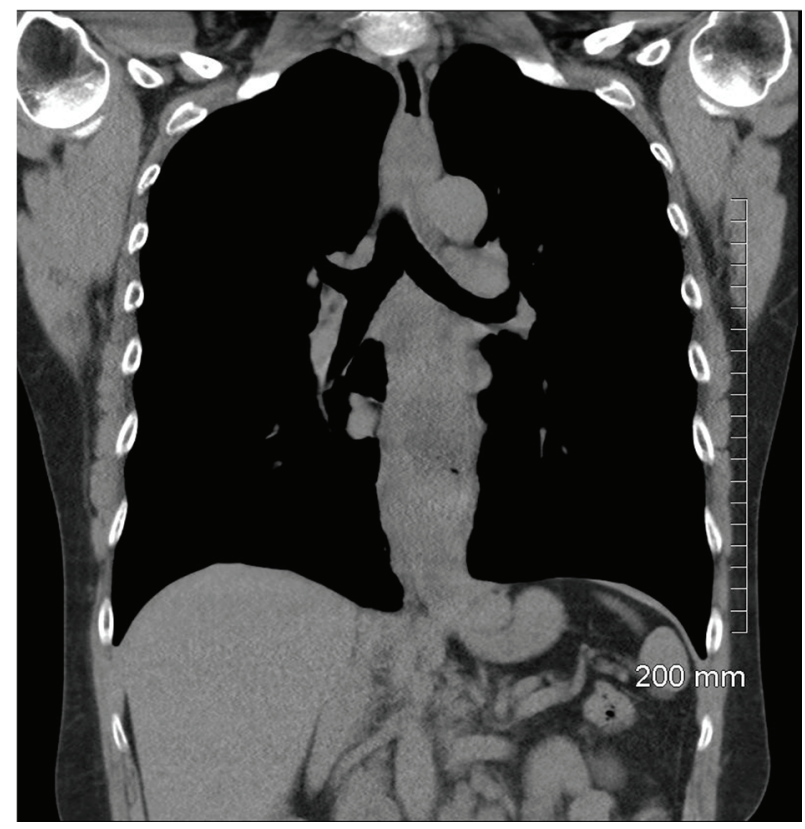

Figure 1. Computed tomography (CT) scan of the chest (coronal view) showing circumferential thickening and irregular enlargement of the esophagus with wall thickening and dilatation. 


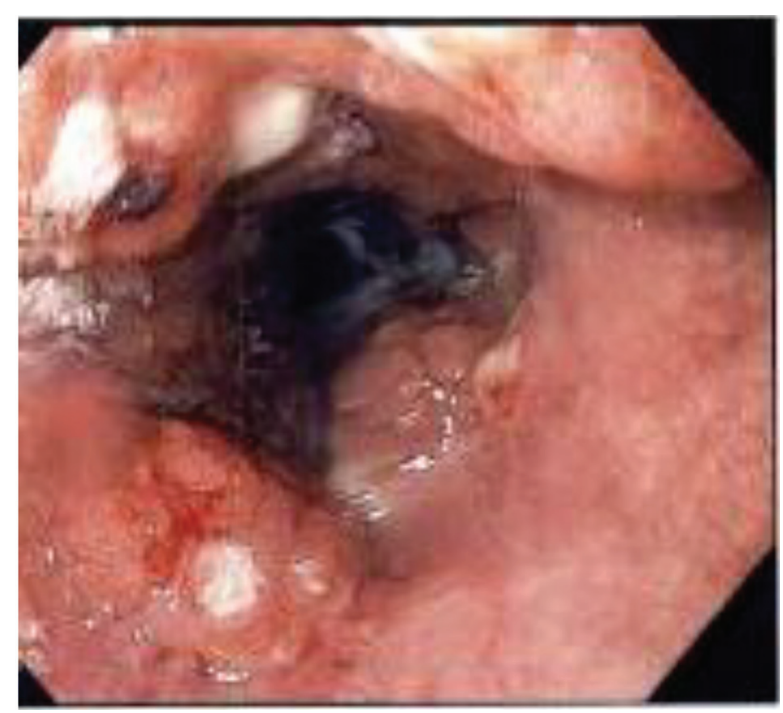

Figure 2. The EGD scope was advanced into the esophagus and almost immediately, a $22 \mathrm{~cm}$ friable fungating mass was seen. There were multiple esophageal masses, which appeared separate.

denied any tobacco smoking or second hand smoking exposure. She consumed two drinks of alcohol on the weekend. She works as a pharmaceutical representative and was on medical leave due to the severe cough during the nights.

She denied any fever, chills or night sweats. She denied any chest pains, heartburn, nausea, vomiting, dysphagia, odynophagia, and weight loss. The patient's vital signs were unremarkable. Her physical examination was unremarkable except for a scattered bibasilar expiratory wheezing in the anterior and posterior lobes.

Recent laboratory workup included a white blood cell (WBC) count of 7.1 cells $/ \mathrm{mL}$, hemoglobin of $15.1 \mathrm{~g} / \mathrm{dL}$, plate-

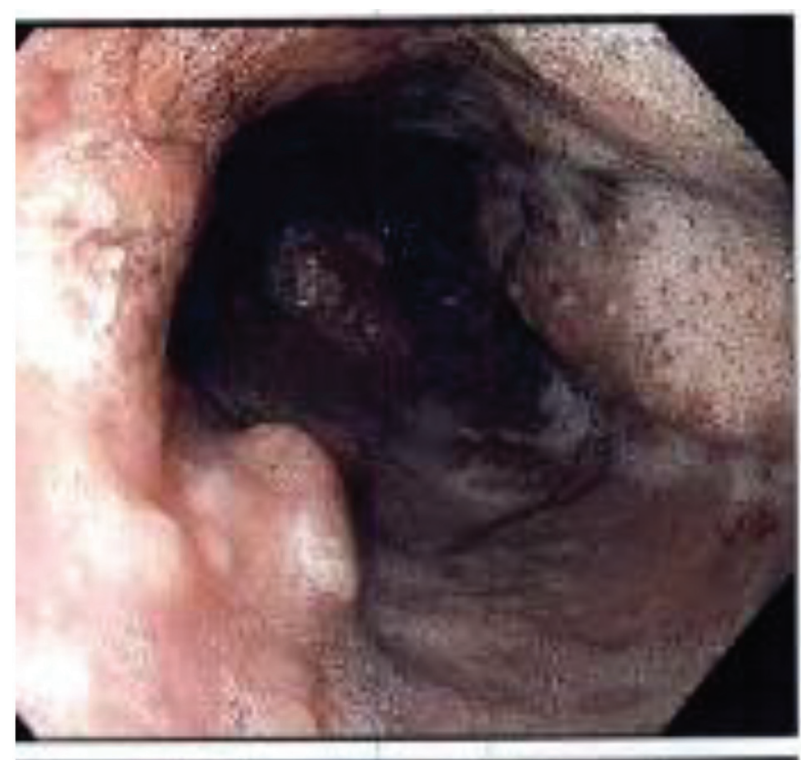

Figure 3. The EGD reveals this friable and fungating mass $30 \mathrm{~cm}$ from the incisors.

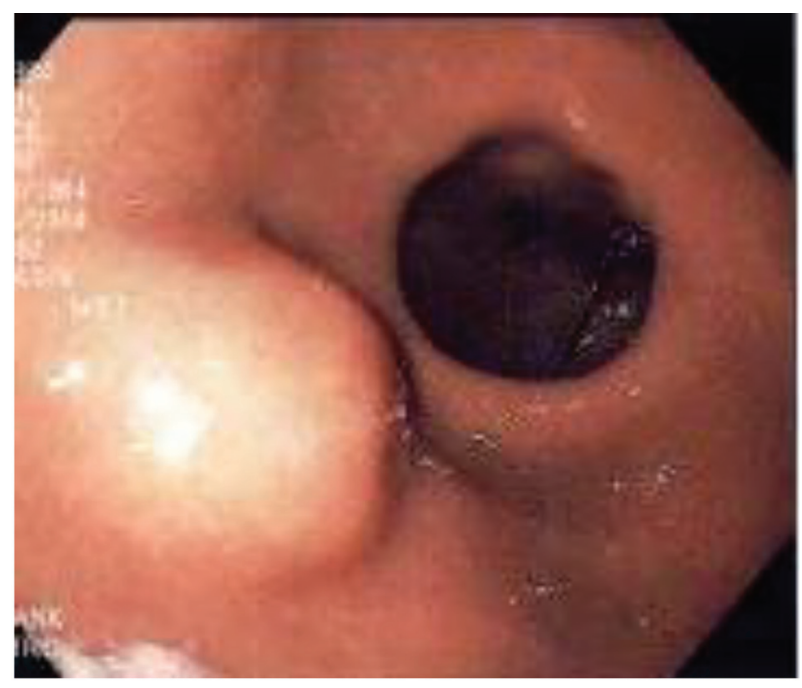

Figure 4. The EGD revealed this friable, large, and smooth mass 35 $\mathrm{cm}$ from the incisors.

lets of $279 / \mathrm{mm}^{3}$, absolute eosinophils of $0.30 \times 10^{3} / \mu \mathrm{L}$, and auto-eosinophils of $4.8 \%$. Other blood tests revealed $\mathrm{Na}$ of $138 \mathrm{mEq} / \mathrm{L}, \mathrm{K}$ of $4.2 \mathrm{mEq} / \mathrm{L}$, creatinine of $1.0 \mathrm{mg} / \mathrm{dL}$, alkaline phosphatase of 61 unit/L, AST of 29 unit/L, ALT of 16 unit/L, and a total bilirubin of $1.0 \mathrm{mg} / \mathrm{dL}$.

Sputum Gram-stain and culture revealed 2+ WBCs, 1+ epithelial cells, normal oropharyngeal flora isolate, and +3 probable Escherichia coli (E. coli) susceptible to cefazolin, cefepime, ciprofloxacin, gentamicin, levofloxacin, meropenem, and trimethaprim/sulfamethoxazole.

The CT scan of the chest (Fig. 1) revealed a markedly abnormal thickening of the thoracic esophagus in the proximal, mid, and distal esophagus that is suspicious for esophageal neoplasm.

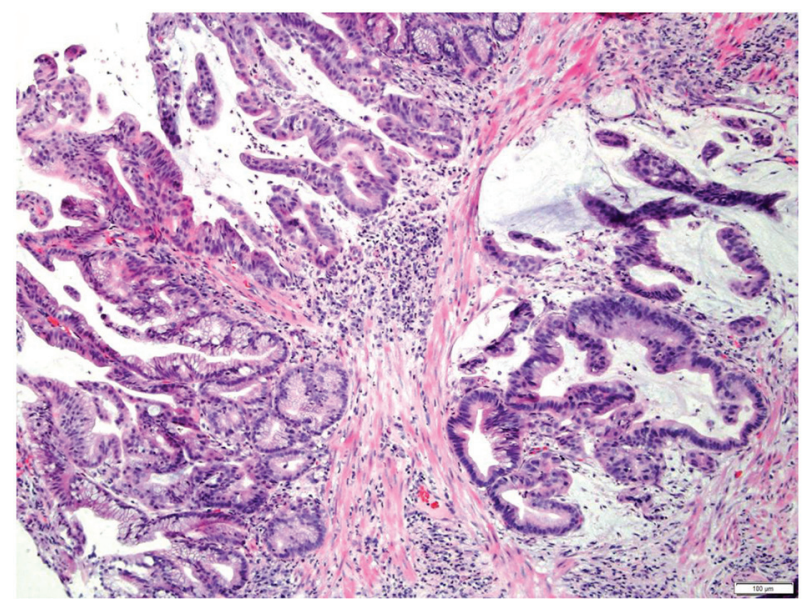

Figure 5. Hematoxylin and eosin (H\&E) stain $(\times 100)$ showing luminal part of malignant glands of adenocarcinoma and submucosal invasive adenocarcinoma showing extracellular mucin. Arc-shaped pink-colored smooth muscle fibers of muscularis mucosae separate the malignant mucosa in the left half of the picture from the submucosal invasive adenocarcinoma in the right half. 


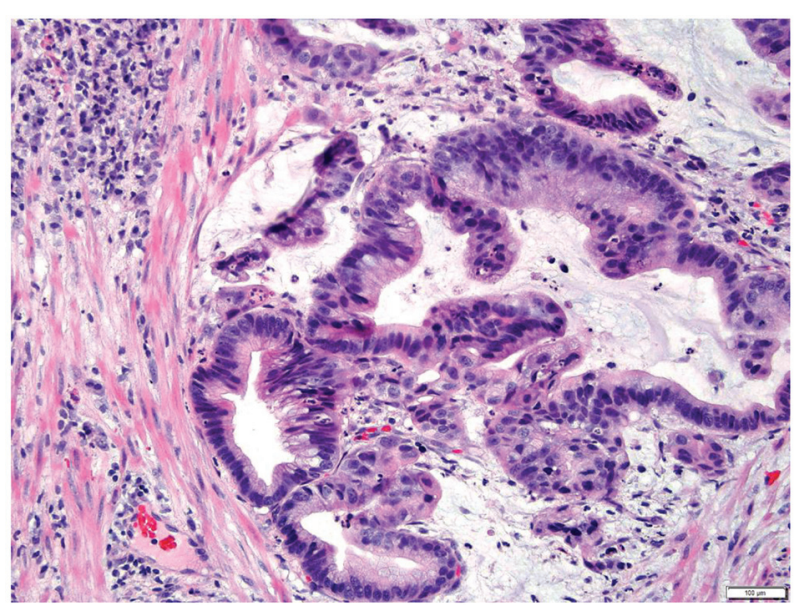

Figure 6. Hematoxylin and eosin stain (H\&E) $(\times 200)$ showing higher magnification of submucosal invasive adenocarcinoma showing extracellular mucin. Submucosal invasive adenocarcinoma shows pleomorphic and hyperchromatic nuclei of the columnar cells with loss of polarity. Submucosal invasive adenocarcinoma is lying under the arc-shaped pink-colored smooth muscle fibers of muscularis mucosae.

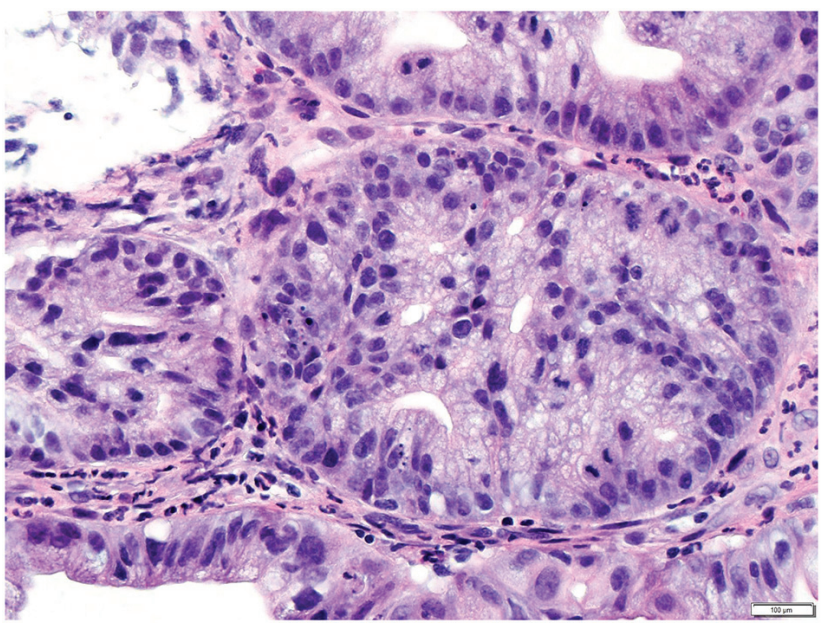

Figure 7. Hematoxylin and eosin (H\&E) stain $(\times 400)$ showing higher magnification of another area of adenocarcinoma with cribriform structures composed of pleomorphic and hyperchromatic nuclei showing a few prominent nucleoli. A few mitotic figures are also seen.

Table 1. Review of the Literature for Esophageal Cancer With an Unusual Presentation [9, 10, 25-38]

\begin{tabular}{|c|c|c|c|c|c|c|c|}
\hline Reference & Age & Gender & Comorbidities & Uncommon presentation & Final diagnosis & Treatment & Outcome \\
\hline [9] & 51 & $\mathrm{M}$ & $\begin{array}{l}\text { Multiple sclerosis, } \\
\text { chronic smoker }\end{array}$ & $\begin{array}{l}\text { Diffuse painless } \\
\text { solid skin nodules }\end{array}$ & $\begin{array}{l}\text { Metastasis from } \\
\text { esophageal cancer }\end{array}$ & $\begin{array}{l}\text { Palliative } \\
\text { chemotherapy }\end{array}$ & \\
\hline$[10]$ & 53 & M & $\begin{array}{l}\text { Alcohol abuse, } \\
\text { chronic smoker }\end{array}$ & $\begin{array}{l}\text { Upper abdominal pain, } \\
\text { post-prandial fullness, } \\
\text { nausea, vomiting }\end{array}$ & $\begin{array}{l}\text { Squamous cell } \\
\text { carcinoma of the } \\
\text { esophagus }\end{array}$ & Palliative therapy & Poor \\
\hline [25] & 50 & M & Chronic smoker & $\begin{array}{l}\text { Left gluteal mass, } \\
\text { dysphagia, odynophagia, } \\
\text { weight loss }\end{array}$ & $\begin{array}{l}\text { Metastasis from } \\
\text { esophageal cancer }\end{array}$ & $\begin{array}{l}\text { Palliative } \\
\text { radiotherapy }\end{array}$ & Poor \\
\hline [26] & 58 & M & $\begin{array}{l}\text { Gastroesophageal } \\
\text { reflux disease, } \\
\text { hyperlipidemia }\end{array}$ & Severe right hip pain & $\begin{array}{l}\text { Skeletal muscle } \\
\text { metastasis from } \\
\text { esophageal cancer }\end{array}$ & - & - \\
\hline [27] & 35 & $\mathrm{~F}$ & None & $\begin{array}{l}\text { Painful right lump breast } \\
\text { mass, weight loss }\end{array}$ & $\begin{array}{l}\text { Metastasis from } \\
\text { esophageal cancer }\end{array}$ & $\begin{array}{l}\text { Radiation therapy, } \\
\text { chemotherapy }\end{array}$ & - \\
\hline [28] & 58 & $\mathrm{~F}$ & $\begin{array}{l}\text { Esophageal cancer } \\
\text { s/p esophago- } \\
\text { gastrectomy }\end{array}$ & Occipital lesion & $\begin{array}{l}\text { Metastasis after } \\
\text { esophago-gastrectomy } \\
\text { from esophageal cancer }\end{array}$ & - & - \\
\hline [29] & 68 & M & None & $\begin{array}{l}\text { Dysphagia, cutaneous } \\
\text { nodules }\end{array}$ & $\begin{array}{l}\text { Metastasis from } \\
\text { esophageal cancer }\end{array}$ & $\begin{array}{l}\text { Chemotherapy, } \\
\text { radiation therapy }\end{array}$ & - \\
\hline [29] & 73 & M & $\begin{array}{l}\text { Esophageal cancer } \\
\text { s/p esophago- } \\
\text { gastrectomy }\end{array}$ & Cutaneous nodules & $\begin{array}{l}\text { Metastasis after } \\
\text { esophago-gastrectomy } \\
\text { from esophageal cancer }\end{array}$ & $\begin{array}{l}\text { Chemotherapy, } \\
\text { radiation therapy }\end{array}$ & - \\
\hline$[30]$ & 59 & M & $\begin{array}{l}\text { Chronic smoker, } \\
\text { chronic bronchitis }\end{array}$ & $\begin{array}{l}\text { Cervical pain and limited } \\
\text { neck mobilization }\end{array}$ & $\begin{array}{l}\text { Metastasis from } \\
\text { esophageal cancer }\end{array}$ & & \\
\hline [31] & 61 & M & None & $\begin{array}{l}\text { Dyspnea, dysphagia, } \\
\text { hoarseness, palpable } \\
\text { thyroid nodule }\end{array}$ & $\begin{array}{l}\text { Metastasis from } \\
\text { esophageal cancer }\end{array}$ & - & $\begin{array}{l}\text { Deceased } \\
\text { due to } \\
\text { advanced } \\
\text { esophageal } \\
\text { cancer }\end{array}$ \\
\hline$[32]$ & 54 & M & $\begin{array}{l}\text { Chronic alcohol, } \\
\text { chronic smoker }\end{array}$ & $\begin{array}{l}\text { Dysphagia, weight loss, } \\
\text { solitary jejunal metastasis }\end{array}$ & $\begin{array}{l}\text { Metastasis from } \\
\text { esophageal cancer }\end{array}$ & $\begin{array}{l}\text { Surgery and } \\
\text { chemotherapy }\end{array}$ & Survived \\
\hline
\end{tabular}


Table 1. Review of the Literature for Esophageal Cancer With an Unusual Presentation [9, 10, 25-38] - (continued)

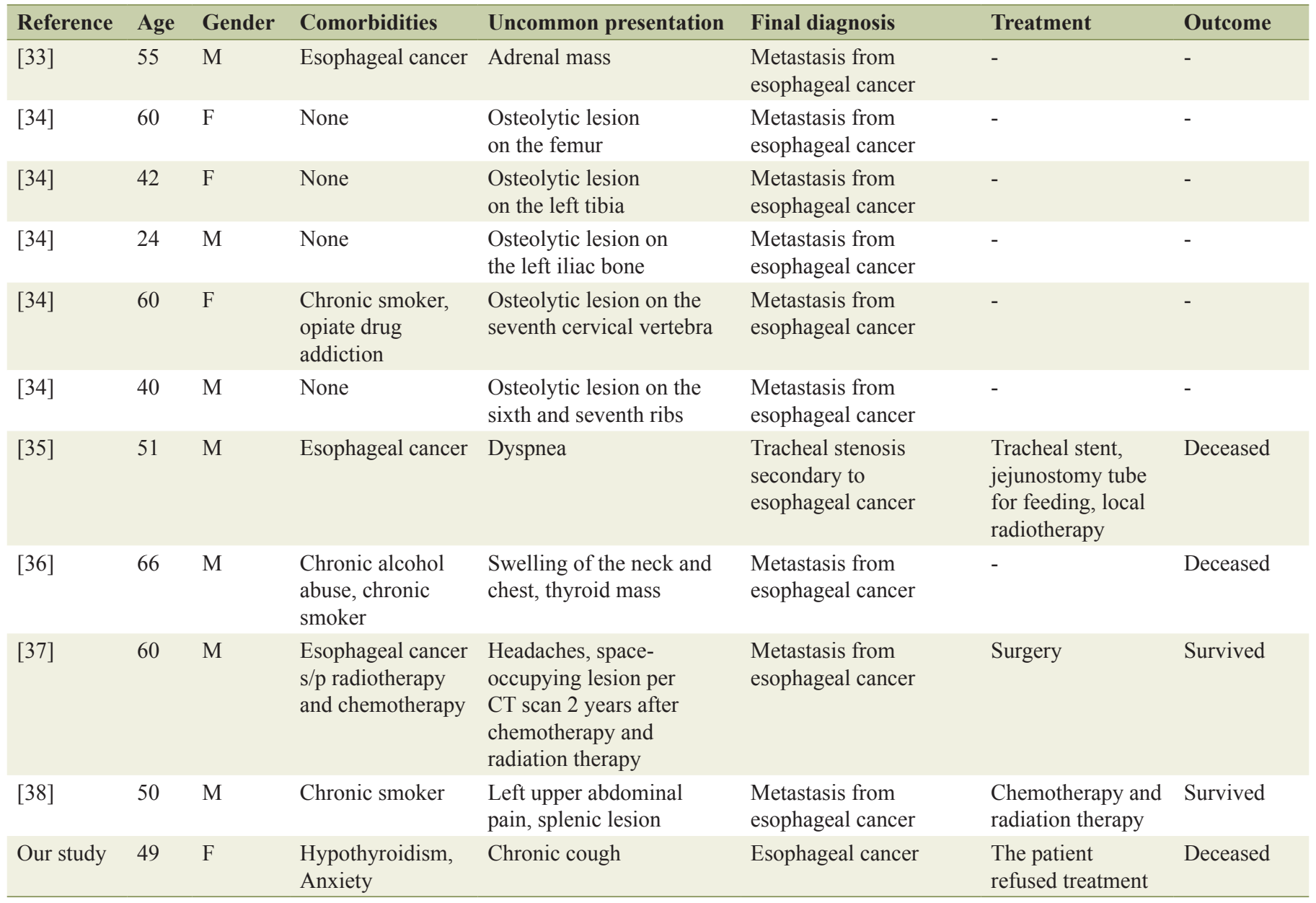

An esophagogastroduodenoscopy (EGD) procedure was performed using an Olympus video gastroscope. The scope was advanced into the esophagus and almost immediately, a 22 $\mathrm{cm}$ friable fungating mass was seen (Fig. 2). There were multiple esophageal masses, which appeared separate. Esophageal biopsies were obtained from three different sites, 25, 30 (Fig. 3), and $35 \mathrm{~cm}$ (Fig. 4) from the incisors.

The pathology report of the mass located at the $25 \mathrm{~cm}$ revealed an invasive adenocarcinoma (Fig. 5-7). The biopsy that was obtained from the 30 and $35 \mathrm{~cm}$ revealed an adenocarcinoma in situ.

Unfortunately, the patient declined further management and passed away 9 months later.

\section{Discussion}

This case is unique due to a number of atypical features. Firstly, the patient had respiratory symptoms rather than gastroenterology symptoms. The most common symptoms for esophageal cancer are dysphagia, odynophagia, and weight loss [2, 3]. Our patient presented with a chronic cough. Esophageal cancer can present with respiratory symptoms of cough and lung infec- tion [16]. This mechanism is commonly due to the presence of an acquired tracheoesophageal fistula (TEF), which the patient did not have. In the literature, there was a case of an esophageal cancer in a patient presenting with acute respiratory symptoms rather the chronic, without a history of respiratory disease or acquired TEF [17-19].

Secondly, EAC arises from the distal third of the esophagus [20]. The unusual location and distribution of the tumor in our case was very rare. The first friable mass was located at 22 $\mathrm{cm}$ from the incisors, which is part of the proximal two-thirds. The lesions were diffuse and extending down $35 \mathrm{~cm}$ from the incisors.

Thirdly, common risk factors for EAC are Barrett's esophagus caused by chronic GERD, low socioeconomic status, obesity, and male gender [21-23]. Higher alcohol consumption was not associated with increased risk of EAC [24]. Our patient did not have any risk factors to suspect esophageal cancer.

In the review of the literature (Table 1) [9, 10, 25-38], $16 / 21$ patients presented with atypical symptoms of either metastatic or non-metastatic esophageal cancer.

Endoscopy with biopsy is the diagnostic test of choice for esophageal cancer [39]. Staging of esophageal cancer should first be done with $\mathrm{CT}$ and positron emission tomography 
(PET)/CT [39]. If the patient is a surgical candidate, endoscopic ultrasonography (EUS) should be used to determine the locoregional extent of disease [39].

\section{Conclusion}

We present a case of an atypical feature of esophageal cancer. It is important for clinicians to keep esophageal cancer in the differential diagnosis in patients presenting with the symptoms previously mentioned.

\section{Disclosure}

This case was presented at the New York Chapter American College of Physicians Annual Meeting.

\section{References}

1. Mir MM, Dar NA. Esophageal cancer in kashmir (India): an enigma for researchers. Int J Health Sci (Qassim). 2009;3(1):71-85.

2. Layke JC, Lopez PP. Esophageal cancer: a review and update. Am Fam Physician. 2006;73(12):2187-2194.

3. Javle M, Ailawadhi S, Yang GY, Nwogu CE, Schiff MD, Nava HR. Palliation of malignant dysphagia in esophageal cancer: a literature-based review. J Support Oncol. 2006;4(8):365-373, 379.

4. Faiz Z, Lemmens VE, Siersema PD, Nieuwenhuijzen GA, Wouters MW, Rozema T, Coebergh JW, et al. Increased resection rates and survival among patients aged 75 years and older with esophageal cancer: a Dutch nationwide population-based study. World J Surg. 2012;36(12):28722878.

5. D'Amico TA. Outcomes after surgery for esophageal cancer. Gastrointest Cancer Res. 2007;1(5):188-196.

6. Yuequan J, Shifeng C, Bing Z. Prognostic factors and family history for survival of esophageal squamous cell carcinoma patients after surgery. Ann Thorac Surg. 2010;90(3):908-913.

7. Zhang Y. Epidemiology of esophageal cancer. World J Gastroenterol. 2013;19(34):5598-5606.

8. Zhang HZ, Jin GF, Shen HB. Epidemiologic differences in esophageal cancer between Asian and Western populations. Chin J Cancer. 2012;31(6):281-286.

9. Iwanski GB, Block A, Keller G, Muench J, Claus S, Fiedler W, Bokemeyer C. Esophageal squamous cell carcinoma presenting with extensive skin lesions: a case report. J Med Case Rep. 2008;2:115.

10. Orlicka K, Maynard S, Bouin M. Unusual presentation of a metastatic esophageal carcinoma. Case Rep Gastroenterol. 2012;6(2):273-278.

11. Enzinger PC, Mayer RJ. Medical Progress: Oesophageal cancer. N Eng J Med. 2003;349:2241-2252.

12. Quint LE, Hepburn LM, Francis IR, Whyte RI, Orringer MB. Incidence and distribution of distant metastases from newly diagnosed esophageal carcinoma. Cancer.
1995;76(7):1120-1125.

13. Stein HJ, Feith M, Bruecher BL, Naehrig J, Sarbia M, Siewert JR. Early esophageal cancer: pattern of lymphatic spread and prognostic factors for long-term survival after surgical resection. Ann Surg. 2005;242(4):566-573; discussion 573-565.

14. Ilson DH. Esophageal cancer chemotherapy: recent advances. Gastrointest Cancer Res. 2008;2(2):85-92.

15. Patel AN, Preskitt JT, Kuhn JA, Hebeler RF, Wood RE, Urschel HC, Jr. Surgical management of esophageal carcinoma. Proc (Bayl Univ Med Cent). 2003;16(3):280284.

16. Adler L, Kabnick EM, Patel M, Azueta V, Helfgott A, Alexander LL, Tafreshi M. Tracheoesophageal fistula secondary to esophageal carcinoma presenting with aspiration pneumonia. J Natl Med Assoc. 1985;77(5):401-403.

17. Shambhu S and Cheshire CM. Oesophageal Carcinoma: An Atypical Presentation-A Case Report. British Journal of Medicine \& Medical Research. 2013;3(4):1688-1691.

18. Qaseem A, Wilt TJ, Weinberger SE, Hanania NA, Criner $\mathrm{G}$, van der Molen T, Marciniuk DD, et al. Diagnosis and management of stable chronic obstructive pulmonary disease: a clinical practice guideline update from the American College of Physicians, American College of Chest Physicians, American Thoracic Society, and European Respiratory Society. Ann Intern Med. 2011;155(3):179191.

19. Aggarwal AN. How appropiate is the gold standard for diagnosis of airway obstruction. Lung India. 2008;25(4):139-141.

20. Patti MG, Gantert W, Way LW. Surgery of the esophagus. Anatomy and physiology. Surg Clin North Am. 1997;77(5):959-970.

21. Falk GW. Risk factors for esophageal cancer development. Surg Oncol Clin N Am. 2009;18(3):469-485.

22. Jansson C, Johansson AL, Nyren O, Lagergren J. Socioeconomic factors and risk of esophageal adenocarcinoma: a nationwide Swedish case-control study. Cancer Epidemiol Biomarkers Prev. 2005;14(7):1754-1761.

23. Chen Q, Zhuang H, Liu Y. The association between obesity factor and esophageal caner. J Gastrointest Oncol. 2012;3(3):226-231.

24. Freedman ND, Murray LJ, Kamangar F, Abnet CC, Cook $\mathrm{MB}$, Nyren $\mathrm{O}$, Ye W, et al. Alcohol intake and risk of oesophageal adenocarcinoma: a pooled analysis from the BEACON Consortium. Gut. 2011;60(8):1029-1037.

25. Smyth S, O'Donnell ME, Kumar S, Hussain A, Cranley B. Atypical presentation of an oesophageal carcinoma with metastases to the left buttock: a case report. Cases J. 2009;2:6691.

26. Norris WE, Perry JL, Moawad FJ, Horwhat JD. An unusual presentation of metastatic esophageal adenocarcinoma presenting as thigh pain. J Gastrointestin Liver Dis. 2009;18(3):371-374.

27. Norooz MT, Montaser-Kouhsari L, Ahmadi H, Zavarei MJ, Daryaei P. Breast mass as the initial presentation of esophageal carcinoma: a case report. Cases J. 2009;2:7049.

28. Park JM, Kim DS, Oh SH, Kwon YS, Lee KH. A case 
of esophageal adenocarcinoma metastasized to the scalp. Ann Dermatol. 2009;21(2):164-167.

29. Herbella FA, Patti MG, Takassi GF. Skin metastases from esophageal and esophagogastric junction cancer. J Gastrointest Oncol. 2011;2(2):104-105.

30. Alvarez Diaz H, Aznar MU, Afonso Afonso FJ. Bone lesions simulating multiple myeloma: unusual presentation of esophageal cancer. Eur J Intern Med. 2009;20(1):e14.

31. Chen ED, Cheng P, Yan XQ, Ye YL, Chen CZ, Ji XH, Zhang XH. Metastasis of distal esophageal carcinoma to the thyroid with presentation simulating primary thyroid carcinoma: a case report and review of the literature. World J Surg Oncol. 2014;12:106.

32. Lindenmann J, Gollowitsch F, Matzi V, Porubsky C, Maier A, Smolle-Juettner FM. Occult solitary submucosal jejunal metastasis from esophageal carcinoma. World J Surg Oncol. 2005;3:44.

33. Kashyap R, Mittal BR, Bhattacharya A, Singh B. Unusual presentation of oesophageal carcinoma with adrenal metastasis. Indian J Nucl Med. 2012;27(3):181-182.

34. Rezaee H, Rahimi B. Squamous cell carcinoma of esoph- agus preenting as bone metastases in five cases. The Iranian Journal of Otorhinolaryngology. 2007;19(49):9-14.

35. Lin SH, Yeh TC, Wang CS, et al. Unusual Presentation of Esophageal Cancer. J Emerg Crit Care Med. 2013;24(4):147-148.

36. Moulick A, Guha P, Das A, Das AK. Squamous cell carcinoma of proximal esophagus with simultaneous metastases to thyroid and sternum: a case report and review of the literature. Tanaffos. 2012;11(1):67-70.

37. Agrawal R, Shukla P, Shukla V, Chauhan A. Brain metastasis from esophageal carcinoma. J Cancer Res Ther. 2009;5(2):137-139.

38. Cavanna L, Lazzaro A, Trabacchi E, Anselmi E, Vallisa D, Foroni RP. Presentation of esophageal cancer with solitary splenic metastasis. Am J Clin Oncol. 2005;28(6):636637.

39. Varghese TK, Jr., Hofstetter WL, Rizk NP, Low DE, Darling GE, Watson TJ, Mitchell JD, et al. The society of thoracic surgeons guidelines on the diagnosis and staging of patients with esophageal cancer. Ann Thorac Surg. 2013;96(1):346-356. 